\title{
Cardiac necklace in rheumatic heart disease
}

\author{
Abhijit V Kulkarni, Subramani K Shankar Rao, Rajiv Ananthakrishna, Manjunath C Nanjappa \\ Cardiology Department, Sri Jayadeva Institute of Cardiovascular Sciences and Research, Bangalore, Karnataka, India
}

Correspondence to Dr Rajiv Ananthakrishna, rajiva.ms@gmail.com

\section{DESCRIPTION}

A 45-year-old male, a known case of rheumatic heart disease (RHD), presented with New York Heart Association (NYHA) class III breathlessness of 6 months duration. There was no history of tuberculosis, diabetes mellitus or chronic kidney disease. A transthoracic echocardiogram showed severe mitral stenosis with an orifice area of 0.9 $\mathrm{cm}^{2}$ and a valve gradient of 23/16 $\mathrm{mm} \mathrm{Hg}$. The Wilkins score was 9 (leaflet mobility 3, valvular thickening 3, subvalvular fusion 2 and calcification 1). Percutaneous transluminal mitral commissurotomy (PTMC) was planned. Fluoroscopy of the chest in the anteroposterior view revealed atrio-ventricular (AV) groove calcification, resembling a 'necklace' (figure 1). PTMC was performed successfully (figure 2) and the patient is in NYHA class I at 6 months follow-up. The most common site of calcium deposits in RHD are the valve leaflets. Sometimes this extends to involve the valve ring. AV groove calcification in RHD, as seen in our case, is an extremely rare occurrence. It is possible that it represents a degenerative, calcific process of RHD which extends beyond the endocardium to involve the AV groove. The clinical presentation in the present report was due to severe mitral stenosis. Long-term follow-up is essential, as the physiological consequences of calcification in non-valvar sites are uncertain. There is a lack of data regarding the possibility

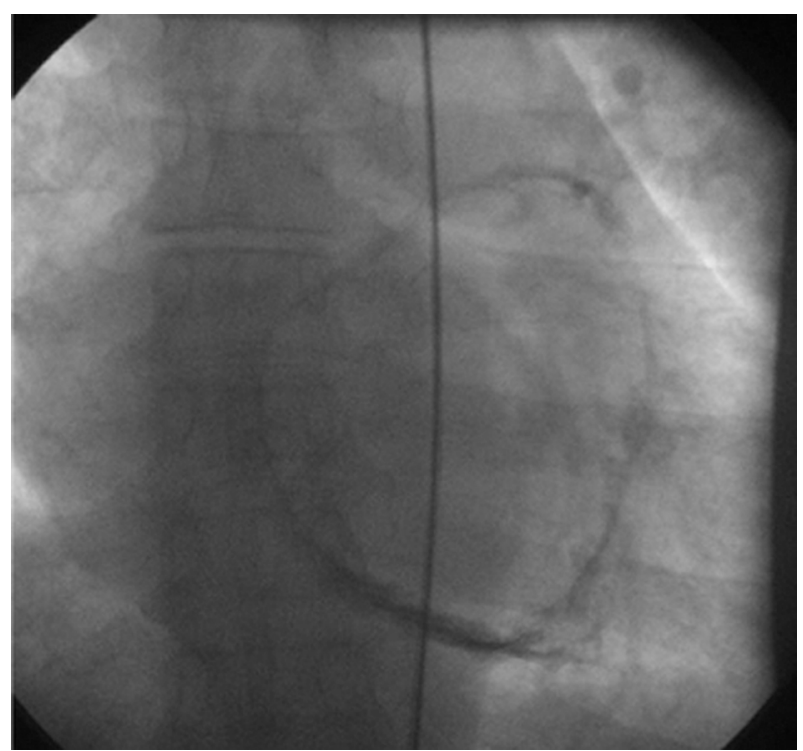

Figure 1 Fluoroscopy in anteroposterior view depicting atrioventricular groove calcification, resembling a necklace. of the development of constrictive physiology. However, $\mathrm{AV}$ groove constriction is possible, considering the site of calcification. Such cases usually present with progressive breathlessness on exertion, with a mid-diastolic murmur at the apex, simulating mitral stenosis. Therefore, in RHD, if there is a progressive worsening of cardiovascular disability, constrictive physiology secondary to AV groove calcification should be considered in the differential diagnosis. Identification of similar patients and long-term follow-up will shed light on the possible association. The Wilkins scoring system involves leaflet rigidity, leaflet thickening, valvular calcification and subvalvular disease. AV groove calcification is not included and the score remains unaffected. The main aim of PTMC is commissural separation for symptomatic relief. There appears to be no risk for haemopericardium in the presence of AV groove calcification. The consequences of balloon oversizing and inflation are valve tear and severe mitral regurgitation rather than haemopericardium.

Competing interests None.

Patient consent Obtained.

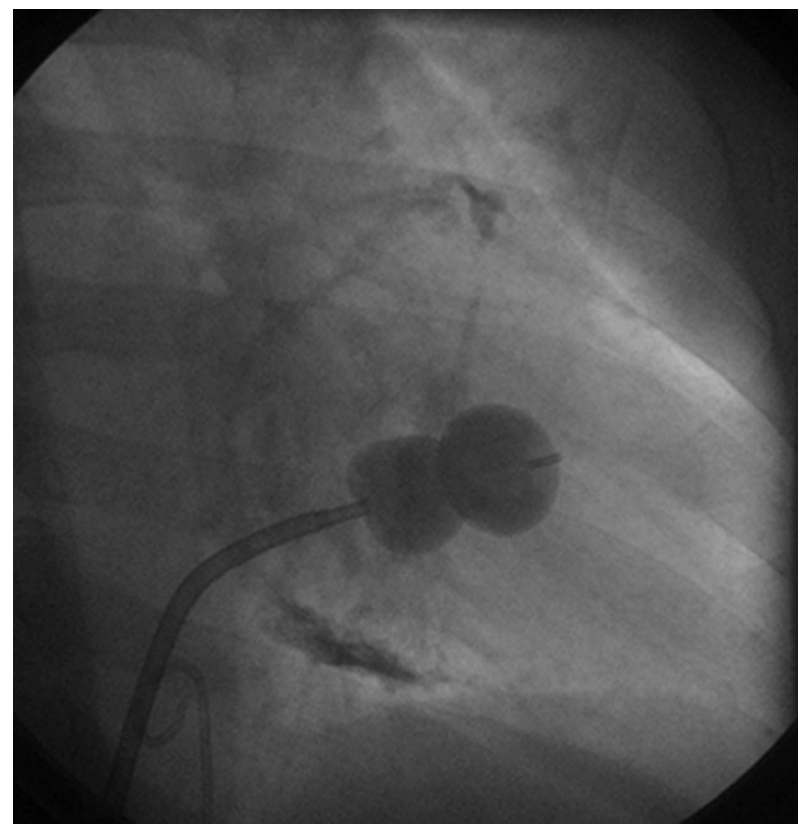

Figure 2 Fluoroscopy depicting the percutaneous transluminal mitral commissurotomy balloon across the mitral valve being inflated. In addition, atrio-ventricular groove calcification can be appreciated. 


\section{BMJ Case Reports}

This pdf has been created automatically from the final edited text and images.

Copyright 2012 BMJ Publishing Group. All rights reserved. For permission to reuse any of this content visit http://group.bmj.com/group/rights-licensing/permissions.

BMJ Case Report Fellows may re-use this article for personal use and teaching without any further permission.

Please cite this article as follows (you will need to access the article online to obtain the date of publication).

Kulkarni AV, Shankar Rao SK, Ananthakrishna R, Nanjappa MC. Cardiac necklace in rheumatic heart disease. BMJ Case Reports 2012;

10.1136/bcr.08.2011.4593, Published XXX

Become a Fellow of BMJ Case Reports today and you can:

- Submit as many cases as you like

- Enjoy fast sympathetic peer review and rapid publication of accepted articles

- Access all the published articles

- Re-use any of the published material for personal use and teaching without further permission

For information on Institutional Fellowships contact consortiasales@bmjgroup.com

Visit casereports.bmj.com for more articles like this and to become a Fellow 